\title{
Gambaran Lingkungan Kerja di Bagian Produksi Beton Bertulang Besi PT X SINGOSARI Malang Jawa Timur
}

\author{
Riris Fitriana Lingga*, Marji, Muhammad Al-Irsyad \\ Universitas Negeri Malang, Jl. Semarang No. 5 Malang, Jawa Timur, Indonesia \\ *Penulis korespondensi, Surel: ririslingga18@gmail.com
}

Paper received: 2-12-2021; revised: 20-12-2021; accepted: 28-12-2021

\begin{abstract}
Work accidents that occur in the workplace 24 percent are caused by the environment or equipment that is not up to standard. The physically affecting environment of work space, lighting, air temperature in the workplace, color of the workspace, cleanliness, and also the media used to provide entertainment to workers. PT X Singosari is one of the PTs that produces iron reinforced concrete by using work tools in the form of machines and materials needed in accordance with production needs. This type of research is a qualitative study with observational descriptive design. The research instruments are environmental health measuring instruments and observation sheets. Data collection techniques by way of interviews, observations, and also measuring the conditions of the work environment. The final result of the study showed that the results of the unmet observations by the different levels of the operating are include 11 sub-indicators, the mixer work area 10 subindicators, the printing work area 10 sub-indicators, the loading work area 4 sub-indicators, and the concrete checking laboratory area 8 sub-indicators. The results of measuring the intensity of lighting in the iron, printing and loading work areas are up to standard, while the mixer and laboratory work areas are not up to standard. The temperature in the concrete and checking laboratory area is up to standard, while the temperature in iron, mixer, printing and loading is not up to standard. Noise in the iron work area, printing, loading and concrete checking laboratory is in accordance with the standard, while the mixer work area is not up to standard.
\end{abstract}

Keywords: work environment; concrete

\begin{abstract}
Abstrak
Kecelakaan kerja yang terjadi di tempat kerja 24 persen disebabkan oleh lingkungan atau peralatan yang tidak sesuai standar. Lingkungan secara fisik yang mempengaruhi kinerja yaitu ruangan kerja, penerangan, kebisingan, suhu udara di tempat kerja, warna ruangan kerja, kebersihan, dan juga media yang digunakan untuk memberikan hiburan kepada pekerja. PT X Singosari merupakan salah satu PT yang melakukan produksi beton bertulang besi dengan menggunakan alat kerja berupa mesin dan material yang dibutuhkan sesuai dengan kebutuhan produksi. Jenis penelitian ini adalah penelitian kualitatif dengan desain deskriptif observasional. Instrumen penelitian yaitu alat ukur environmental health dan lembar observasi. Teknik pengumpulan data yaitu dengan cara wawancara, observasi, dan juga pengukuran kondisi lingkungan kerja. Hasil akhir dari penelitian didapatkan hasil observasi yang belum terpenuhi dengan jumlah berbeda yaitu Area kerja pembesian terdapat 11 sub indikator, area kerja mixer 10 sub indikator, area kerja pencetakan 10 sub indikator, area kerja pemuatan 4 sub indikator, dan area laboratorium pengecekan beton 8 sub indikator. Hasil pengukuran intensitas pencahayaan di area kerja pembesian, pencetakan dan pemuatan sudah sesuai standar sedangkan area kerja mixer dan laboratorium belum sesuai standar. Suhu di area laboratorium pengecekan beton sudah sesuai standar sedangkan suhu di pembesian, mixer, pencetakan dan pemuatan belum sesuai standar. Kebisingan di area kerja pembesian, pencetakan, pemuatan dan laboratorium pengecekan beton sudah sesuai dengan standar sedangkan area kerja mixer belum sesuai standar.
\end{abstract}

Kata kunci: lingkungan kerja; beton 


\section{Pendahuluan}

Kecelakaan kerja salah satu permasalahan yang sering terjadi pada pekerja yang mana kejadian ini disebabkan beberapa faktor diantaranya adalah lingkungan kerja yang tidak sesuai (Aswar et al., 2016). Lingkungan kerja secara fisik yang mempengaruhi kinerja yaitu ruangan kerja, penerangan, kebisingan, suhu udara di tempat kerja, warna ruangan kerja, kebersihan, dan juga media yang digunakan untuk memberikan hiburan kepada pekerja. Lingkungan kerja merupakan segala hal yang berada disekitar pekerja, sehingga akan mempengaruhi setiap pekerjaan yang dilakukan (Elizar \& Tanjung, 2018).

Lingkungan kerja yang buruk akan memberi dampak yang buruk bagi karyawan di tempat kerja seperti penerangan yang buruk dapat menyebabkan kelelahan mata bagi pekerja sehingga konsentrasi pekerja berkurang dan juga menyebabkan kelelahan mental, pegal di daerah mata, sakit kepala disekitar mata, kerusakan mata, dan juga menyebabkan kecelakaan kerja (Odi et al., 2018). Selain itu, Kebisingan juga dapat mengganggu kesehatan pekerja jika terpapar kebisingan yang melebihi nilai ambang batas dengan jangka waktu singkat maupun jangka panjang. Intensitas kebisingan yang didengarkan apabila melalui nilai ambang batas yang ditentukan dapat menyebabkan kehilangan pendengaran sementara sampai permanen, pusing, tekanan darah tinggi, stres secara emosional, dapat juga sakit jantung, dan kehilangan konsentrasi saat melakukan pekerjaan (Amir et al., 2019). Suhu lingkungan kerja juga sangat berpengaruh dalam proses kerja dan mempengaruhi kesehatan setiap pekerja.

Lingkungan kerja yang baik akan membuat karyawan tenang dalam melakukan pekerjaan sehingga pekerja tetap semangat dalam melakukan pekerjaan dan dengan hasil kerja yang memuaskan. Sebaliknya, jika lingkungan kerja buruk maka pekerja akan mudah merasa lelah dan bosan sehingga dapat mengganggu proses kerja (Ningrum et al., 2014). Sehingga, pihak perusahaan harus memperhatikan setiap kondisi lingkungan tempat kerja karena lingkungan kerja yang sangat mempengaruhi kenyamanan setiap pekerja dalam melakukan setiap tanggung jawab pekerjaanya (Senata et al., 2014).

PT X Singosari merupakan salah satu PT yang melakukan produksi beton bertulang besi dengan menggunakan alat kerja berupa mesin dan material yang dibutuhkan sesuai dengan kebutuhan produksi. Berdasarkan observasi awal yang dilakukan didapatkan realita bahwa lingkungan kerja pada PT X belum ada pembatas beton antara tempat pengelasan, pembesian, percetakan beton, pemuatan, mixer bahan dan stok barang serta berada dalam ruangan terbuka yang hanya memiliki atap saja. Untuk ruangan pembuatan mebel, laboratorium pengecekan beton, dan penyimpanan genset sudah berada dalam ruangan yang berbeda dan ada pembatas yang jelas. Selain itu, juga didapatkan hasil bahwa terdapat beberapa hal yang belum terpenuhi seperti poster penanda area tertentu, poster kewajiban menggunakan APD yang sesuai, belum adanya tempat untuk membuang bahan yang sudah tidak terpakai, dan material atau alat yang digunakan belum tertata secara rapi. Mesin kerja yang digunakan menghasilkan suara atau kebisingan yang dapat mempengaruhi kesehatan para pekerja serta penggunaan APD yang belum sesuai saat melakukan pekerjaan. Sedangkan, berdasarkan Peraturan Pemerintah RI No. 50 Tahun 2012 tentang Penerapan Sistem Manajemen Keselamatan dan Kesehatan Kerja dijelaskan bahwa pihak perusahaan melakukan perencanaan K3, pelaksanaan rencana K3, pemantauan dan evaluasi kinerja K3 serta peninjauan dan peningkatan kinerja SMK3 di tempat kerja guna meningkatkan kesehatan dan keselamatan kerja. 
Sesuai dengan latar belakang permasalahan yang telah dikemukakan sebelumnya, adapun tujuan mengadakan penelitian berjudul "Gambaran Lingkungan Kerja PT X Singosari" adalah untuk mengetahui gambaran lingkungan kerja di PT X singosari apakah sudah sesuai dengan standar yang ditetapkan, sehingga memberikan informasi yang sesuai kepada pembaca tentang lingkungan fisik PT X Singosari pada saat ini.

\section{Metode}

Jenis penelitian ini adalah penelitian kualitatif dengan desain deskriptif observasional. Penelitian ini dilakukan di PT X Singosari pada bulan November 2020 sampai dengan bulan Januari 2021.Data yang digunakan dalam penelitian ini adalah data primer. Dalam penelitian ini populasi yang diambil oleh peneliti adalah objek tempat kerja yaitu area kerja PT X Singosari. Instrumen yang digunakan dalam penelitian ini adalah alat ukur environmental health untuk mengukur kondisi lingkungan kerja seperti suhu, pencahayaan, dan kebisingan dan lembar observasi untuk mengecek kelayakan dari tempat kerja. Teknik pengumpulan data pada penelitian ini adalah dengan cara wawancara, observasi, dan juga pengukuran kondisi lingkungan kerja secara langsung. Analisis data menggunakan metode kualitatif. Analisis data kualitatif digunakan untuk menganalisis hasil penelitian yang dilakukan melalui teknik pengumpulan data yang sudah ditentukan dan menarik kesimpulan (Prayoga et al., 2020).

\section{Hasil dan Pembahasan}

\subsection{Hasil}

\subsubsection{Data Observasi}

Tabel 1. Hasil Observasi Bagian Pembesian, Mixer, Pencetakan, Pemuatan, dan Laboratorium Pengecekan Beton

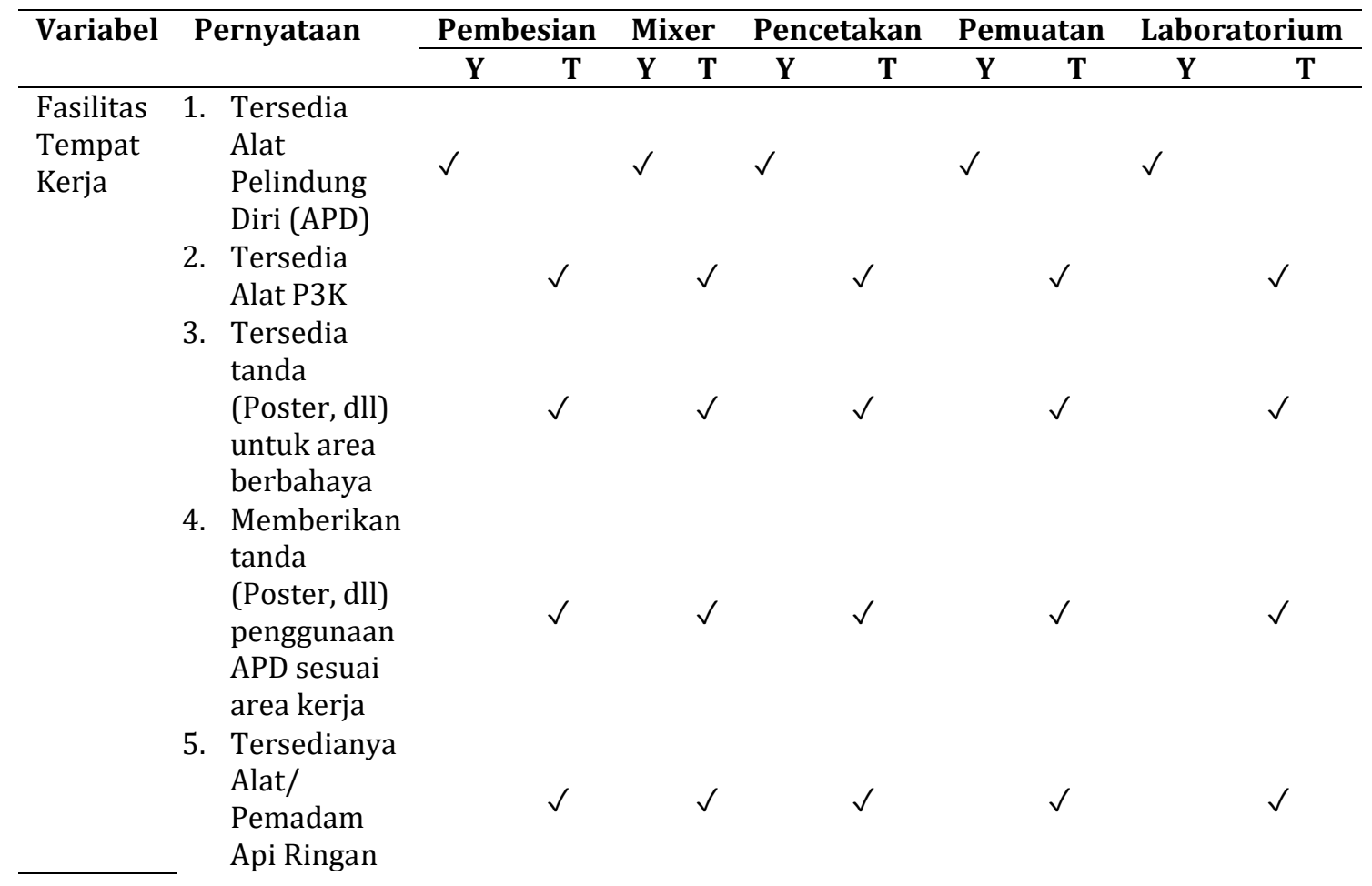




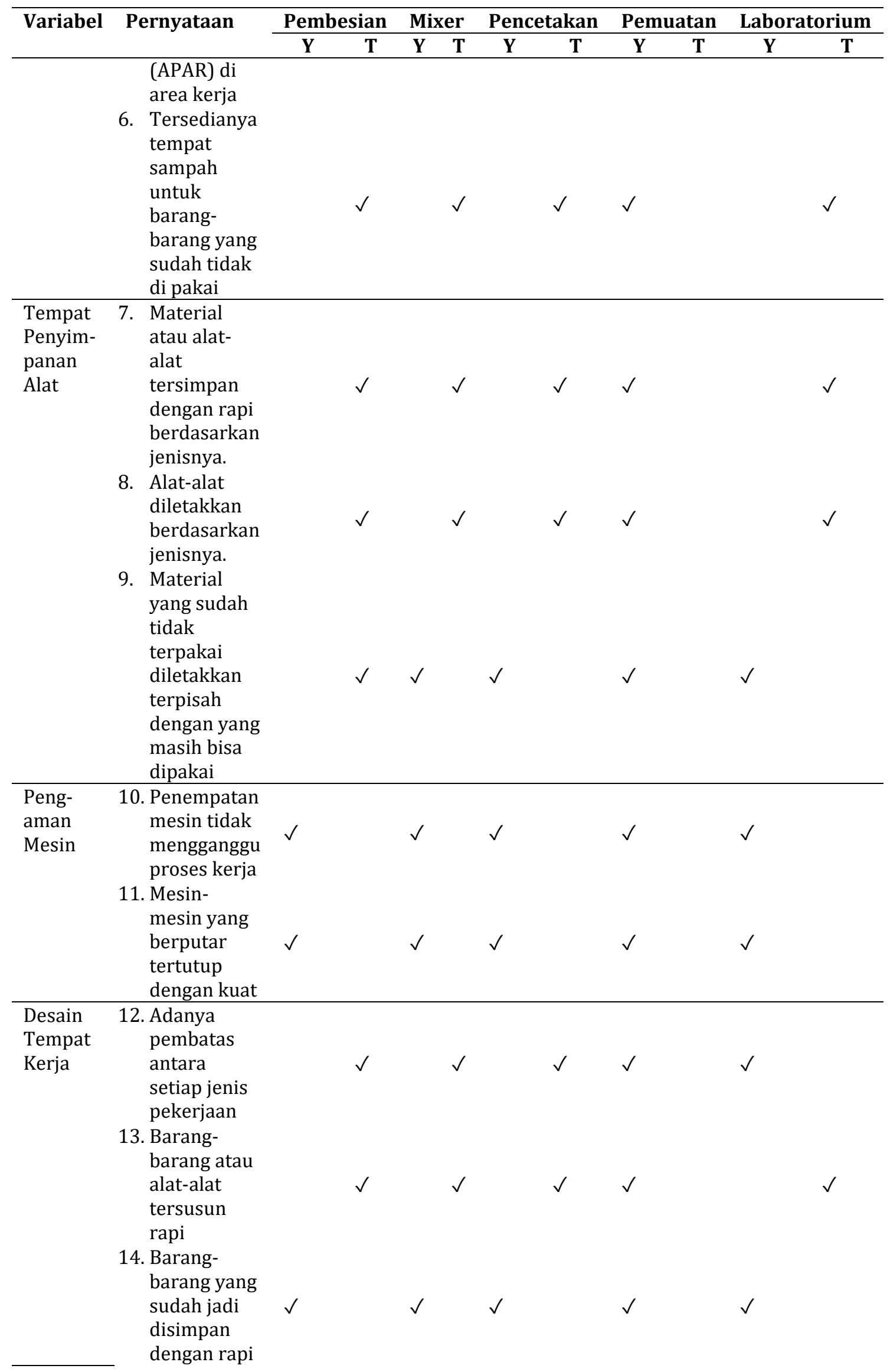




\begin{tabular}{|c|c|c|c|c|c|c|c|c|c|c|c|}
\hline \multirow[t]{2}{*}{ Variabel } & \multirow[t]{2}{*}{ Pernyataan } & \multicolumn{2}{|c|}{ Pembesian } & \multicolumn{2}{|c|}{ Mixer } & \multicolumn{2}{|c|}{ Pencetakan } & \multicolumn{2}{|c|}{ Pemuatan } & \multicolumn{2}{|c|}{ Laboratorium } \\
\hline & & $\mathbf{Y}$ & $\mathbf{T}$ & $\mathbf{Y}$ & $\mathbf{T}$ & $\mathbf{Y}$ & $T$ & $\mathbf{Y}$ & $T$ & $\mathbf{Y}$ & $T$ \\
\hline & $\begin{array}{l}\text { 15. Mesin- } \\
\text { mesin } \\
\text { terletak di } \\
\text { tempatnya } \\
\text { sesuai } \\
\text { dengan } \\
\text { kebutuhan } \\
\text { pekerjaan }\end{array}$ & $\checkmark$ & & $\checkmark$ & & $\checkmark$ & & $\checkmark$ & & $\checkmark$ & \\
\hline & $\begin{array}{l}\text { 16. Memiliki } \\
\text { sirkulasi } \\
\text { udara atau } \\
\text { ruangan } \\
\text { tidak } \\
\text { pengap }\end{array}$ & $\checkmark$ & & $\checkmark$ & & $\checkmark$ & & $\checkmark$ & & $\checkmark$ & \\
\hline & $\begin{array}{l}\text { 17. Permukaan } \\
\text { lantai rata } \\
\text { dan tidak } \\
\text { licin }\end{array}$ & & $\checkmark$ & & $\checkmark$ & & $\checkmark$ & $\checkmark$ & & $\checkmark$ & \\
\hline
\end{tabular}

Dari hasil observasional yang telah dilakukan di lima area kerja yang dipaparkan pada tabel 1 yaitu pada area kerja pembesian didapatkan hasil dari 17 sub indikator terdapat 11 sub indikator yang masih belum terpenuhi, area kerja mixer didapatkan hasil dari 17 sub indikator terdapat 10 sub indikator yang masih belum terpenuhi, area kerja pencetakan didapatkan hasil dari 17 sub indikator terdapat 10 sub indikator yang masih belum terpenuhi, area kerja pemuatan didapatkan hasil dari 17 sub indikator terdapat 4 sub indikator yang masih belum terpenuhi, dan area kerja laboratorium pengecekan beton didapatkan hasil dari 17 sub indikator terdapat 8 sub indikator yang masih belum terpenuhi.

Berikut merupakan hasil pengukuran lingkungan fisik yang sudah dilakukan. Berdasarkan hasil pengukuran yang dilakukan menggunakan alat environmental health di area pembesian didapatkan hasil untuk suhu sebesar $29,1^{\circ} \mathrm{C}$, pencahayaan sebesar 827 lux, dan kebisingan sebesar 74,2 dB.

\subsubsection{Data Hasil Pengukuran Lingkungan Fisik}

\subsubsection{Hasil pengukuran Lingkungan Fisik Area Pembeseian}

Tabel 2. Hasil Pengukuran Kebisingan Bagian Pembesian

\begin{tabular}{|c|c|c|c|c|}
\hline \multicolumn{4}{|c|}{ Bagian Pembesian } & \multirow{2}{*}{ Hasil } \\
\hline Menit & dB & Menit & dB & \\
\hline 5 & 68,1 & 35 & 78,3 & \multirow{6}{*}{74,19} \\
\hline 10 & 71,3 & 40 & 73,0 & \\
\hline 15 & 72,0 & 45 & 76,2 & \\
\hline 20 & 71,4 & 50 & 72,8 & \\
\hline 25 & 78,0 & 55 & 71,8 & \\
\hline 30 & 70,2 & 60 & 72,8 & \\
\hline
\end{tabular}

Tabel diatas menunjukkan hasil pengukuran kebisingan selama satu menit dan didapatkan hasil rata-rata pengukuran dengan nilai kebisingan 74,19 dB. 


\subsubsection{Hasil Pengukuran Lingkungan Fisik di Area Mixer}

Berdasarkan hasil pengukuran yang dilakukan menggunakan alat environmental health di area mixer didapatkan hasil untuk suhu sebesar $30,6^{\circ} \mathrm{C}$, pencahayaan sebesar 204 lux, dan kebisingan sebesar 86,15 dB.

Tabel 3. Hasil Pengukuran Kebisingan Bagian Mixer

\begin{tabular}{|c|c|c|c|c|}
\hline \multicolumn{4}{|c|}{ Bagian Mixer } & \multirow{2}{*}{ Hasil } \\
\hline Menit & dB & Menit & dB & \\
\hline 5 & 87 & 35 & 85,8 & \multirow{6}{*}{86,15} \\
\hline 10 & 88,5 & 40 & 87,4 & \\
\hline 15 & 83,4 & 45 & 86,8 & \\
\hline 20 & 83,8 & 50 & 83,8 & \\
\hline 25 & 87,9 & 55 & 87,5 & \\
\hline 30 & 85,1 & 60 & 86,8 & \\
\hline
\end{tabular}

Tabel diatas menunjukkan hasil pengukuran kebisingan selama satu menit dan didapatkan hasil rata-rata pengukuran dengan nilai kebisingan 86,15 dB.

\subsubsection{Hasil Pengukuran Lingkungan Fisik di Area Pencetakan}

Berdasarkan hasil pengukuran yang dilakukan menggunakan alat environmental health di area pencetakan didapatkan hasil untuk suhu sebesar $28,2^{\circ} \mathrm{C}$, pencahayaan sebesar 578 lux, dan kebisingan sebesar 80,57 dB.

Tabel 4. Hasil Pengukuran Kebisingan Bagian Pencetakan

\begin{tabular}{|c|c|c|c|c|}
\hline \multicolumn{4}{|c|}{ Bagian Pencetakan } & \multirow{2}{*}{ Hasil } \\
\hline Menit & dB & Menit & $\mathbf{d B}$ & \\
\hline 5 & 78,8 & 35 & 78,2 & \multirow{6}{*}{80,57} \\
\hline 10 & 79,7 & 40 & 77,2 & \\
\hline 15 & 79,5 & 45 & 81,8 & \\
\hline 20 & 80,1 & 50 & 80,1 & \\
\hline 25 & 84,1 & 55 & 80,0 & \\
\hline 30 & 84,5 & 60 & 82,9 & \\
\hline
\end{tabular}

Tabel diatas menunjukkan hasil pengukuran kebisingan selama satu menit dan didapatkan hasil rata-rata pengukuran dengan nilai kebisingan 80,57 dB.

\subsubsection{Hasil Pengukuran Lingkungan Fisik di Area Pemuatan}

Berdasarkan hasil pengukuran yang dilakukan menggunakan alat environmental health di area pemuatan didapatkan hasil untuk suhu sebesar $29,6^{\circ} \mathrm{C}$, pencahayaan sebesar 655 lux, dan kebisingan sebesar 75,53 dB. 
Tabel 5. Hasil Pengukuran Kebisingan Bagian Pemuatan

\begin{tabular}{|c|c|c|c|c|}
\hline \multicolumn{4}{|c|}{ Bagian Pemuatan } & \multirow{2}{*}{ Hasil } \\
\hline Menit & dB & Menit & $\mathbf{d B}$ & \\
\hline 5 & 71,2 & 35 & 75,2 & \multirow{6}{*}{73,53} \\
\hline 10 & 75,5 & 40 & 77,2 & \\
\hline 15 & 74,4 & 45 & 73,9 & \\
\hline 20 & 72,4 & 50 & 71,6 & \\
\hline 25 & 71,2 & 55 & 73,8 & \\
\hline 30 & 72,0 & 60 & 74,00 & \\
\hline
\end{tabular}

Tabel diatas menunjukkan hasil pengukuran kebisingan selama satu menit dan didapatkan hasil rata-rata pengukuran dengan nilai kebisingan 73,53 dB.

\subsubsection{Hasil Pengukuran Lingkungan Fisik di Area Laboratorium Pengecekan Beton}

Berdasarkan hasil pengukuran yang dilakukan menggunakan alat environmental health di area laboratorium pengecekan beton didapatkan hasil untuk suhu sebesar 29,6 ${ }^{\circ} \mathrm{C}$, pencahayaan sebesar 655 lux, dan kebisingan sebesar 75,53 dB.

Tabel 6. Hasil Pengukuran Kebisingan Bagian Laboratorium Pengecekan Beton

\begin{tabular}{ccccc}
\hline \multicolumn{4}{c}{ Bagian Pengecekan Beton } & \multirow{2}{*}{ Hasil } \\
\cline { 1 - 3 } Menit & dB & Menit & dB & \\
\hline 5 & 61,0 & 35 & 61,1 & \\
10 & 58,1 & 40 & 59,4 & \\
15 & 59,9 & 45 & 59,9 & \multirow{2}{*}{60,29} \\
20 & 59,6 & 50 & 58,7 & \\
25 & 58,5 & 55 & 60,1 & \\
30 & 58,3 & 60 & 68,9 & \\
\hline
\end{tabular}

Tabel diatas menunjukkan hasil pengukuran kebisingan selama satu menit dan didapatkan hasil rata-rata pengukuran dengan nilai kebisingan 60,29 dB.

Berikut merupakan hasil pengukuran lingkungan fisik dalam bentuk grafik untuk keseluruhan bagian tempat kerja:

\subsubsection{Hasil Pengukuran Pencahayaan}

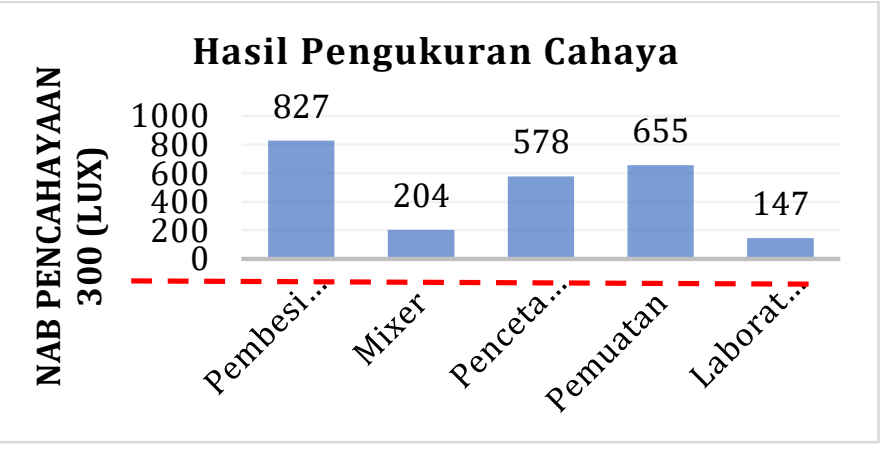

Gambar 1. Grafik Hasil Pengukuran Pencahayaan 
Dari gambar diatas menunjukkan hasil pengukuran pencahayaan di lima tempat di PT X. Dari hasil pengukuran didapatkan bahwa area pembesian, pencetakan, dan pemuatan sudah sesuai dengan standar pencahayaan. Sedangkan untuk area mixer dan laboratorium berada dibawah standar yang seharusnya.

\subsubsection{Hasil Pengukuran Suhu}

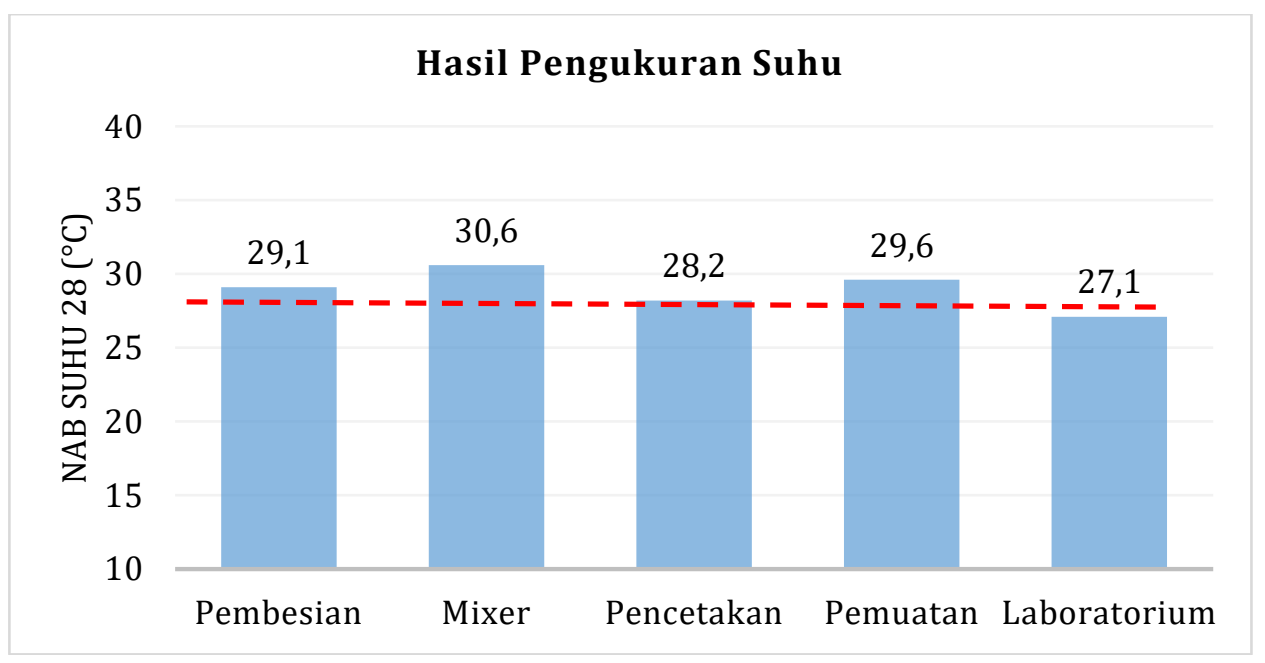

\subsubsection{Hasil Pengukuran Kebisingan}

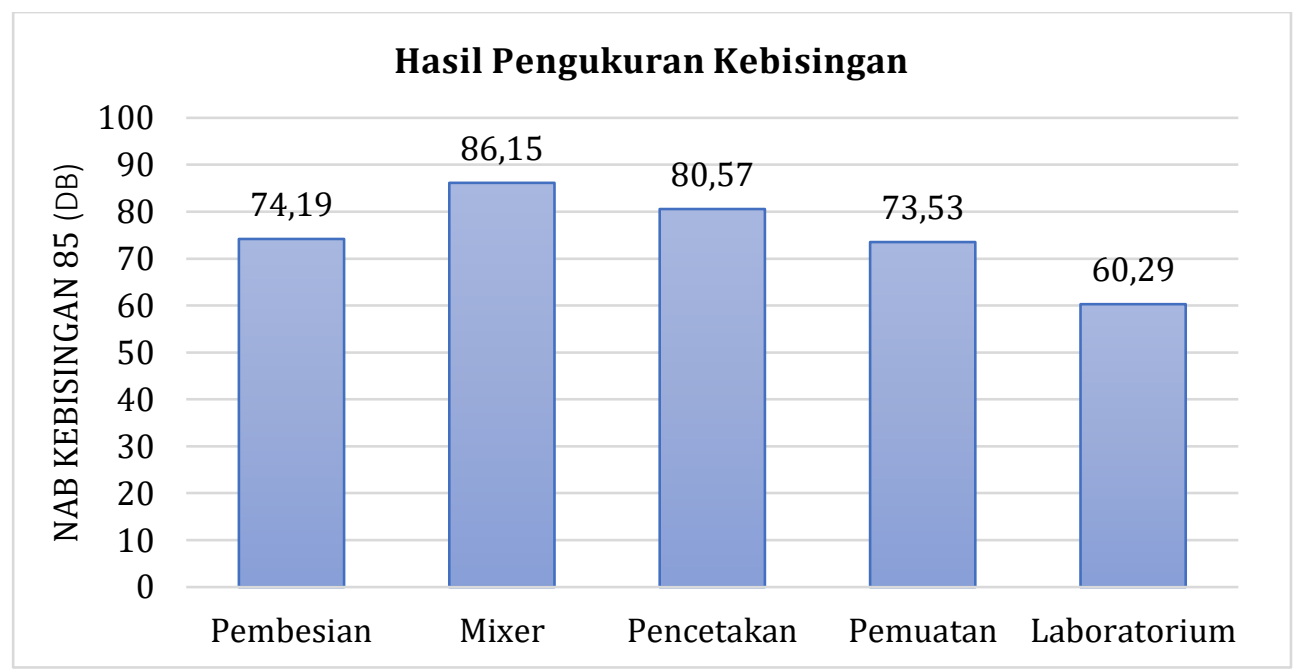

Gambar 3. Grafik Hasil Pengukuran Kebisingan

Dari gambar diatas menunjukkan hasil pengukuran kebisingan kerja di lima tempat di PT X. Dari hasil pengukuran didapatkan bahwa area mixer nilai kebisingan melebihi Nilai Ambang Batas (NAB). Sedangkan untuk area kerja pembesian, pencetakan, pemuatan, dan laboratorium pengecekan sudah sesuai dengan standar karena tidak melebihi Nilai Ambang Batas (NAB) yang sudah ditetapkan. 


\subsubsection{Hasil Wawancara}

Tabel 7. Hasil Wawancara

\begin{tabular}{|c|c|c|c|}
\hline \multirow[t]{2}{*}{ No } & \multirow{2}{*}{ Pertanyaan } & \multicolumn{2}{|c|}{ Hasil Wawancara } \\
\hline & & Bapak R (Pengawas) & Bapak L (Karyawan) \\
\hline \multicolumn{4}{|c|}{ Pertanyaan Umum } \\
\hline 1. & $\begin{array}{l}\text { Apa yang anda ketahui } \\
\text { tentang bahaya yang ada di } \\
\text { tempat kerja? }\end{array}$ & $\begin{array}{l}\text { Di bagian percetakan, } \\
\text { penutup molding bisa } \\
\text { terbuka dan pekerja bisa } \\
\text { terjepit }\end{array}$ & $\begin{array}{l}\text { Ada bahaya yang kecil } \\
\text { seperti licin karena } \\
\text { becek }\end{array}$ \\
\hline 2. & $\begin{array}{l}\text { Sebutkan bahaya kerja yang } \\
\text { mungkin sering terjadi di PT } \\
\text { ini? }\end{array}$ & $\begin{array}{l}\text { Pintu molding yang bisa } \\
\text { terlepas dan menjepit } \\
\text { pekerja }\end{array}$ & $\begin{array}{l}\text { Untuk bahaya diatasi } \\
\text { dengan menggunakan } \\
\text { alat membantu }\end{array}$ \\
\hline 3. & $\begin{array}{l}\text { Apakah bagian lingkungan } \\
\text { kerja seperti suhu ruangan, } \\
\text { pencahayaan, dan kebisingan } \\
\text { sudah sesuai dan tidak } \\
\text { mengganggu } \\
\text { pekerjaan? }\end{array}$ & $\begin{array}{l}\text { Suara mesin-mesin kecil } \\
\text { dari vibrator dan juga } \\
\text { ruangan outdoor jadi tidak } \\
\text { tertutup }\end{array}$ & $\begin{array}{l}\text { Suasana terbuka jadi } \\
\text { menurut raya } \\
\text { kebisingan dan } \\
\text { lainnya hampir tidak } \\
\text { ada }\end{array}$ \\
\hline 4. & $\begin{array}{l}\text { Sebelumnya apakah sudah } \\
\text { pernah } \\
\text { penyelidikan terkait bahaya } \\
\text { kerja di PT ini? }\end{array}$ & $\begin{array}{l}\text { Penyelidikan bahaya kerja } \\
\text { belum ada namun hanya } \\
\text { melaksanakan aturan yang } \\
\text { dimiliki }\end{array}$ & $\begin{array}{lr}\text { Pernah dari } & \text { dinas } \\
\text { lingkungan } & \text { hidup } \\
\text { datang } & \text { untuk } \\
\text { memantau } & \\
\text { lingkungan pabrik }\end{array}$ \\
\hline 5. & $\begin{array}{l}\text { Untuk setiap bahaya kerja } \\
\text { yang ada, pengendalian apa } \\
\text { saja yang sudah dilakukan? }\end{array}$ & $\begin{array}{l}\text { Untuk pengaman pintu } \\
\text { sudah diberikan rantai dan } \\
\text { juga alat pemadam api } \\
\text { tersedia satu di pojok } \\
\text { ruangan }\end{array}$ & $\begin{array}{l}\text { Pengendalian } \\
\text { dilakukan di beberapa } \\
\text { penanganan untuk } \\
\text { kecelakaan kerja yang } \\
\text { dialami }\end{array}$ \\
\hline \multicolumn{4}{|c|}{ Pertanyaan Probability } \\
\hline 1. & $\begin{array}{l}\text { Sebelum melakukan } \\
\text { pekerjaan apakah ada } \\
\text { penjelasan atau pengarahan } \\
\text { yang dilakukan terkait } \\
\text { sistem kerja yang harus } \\
\text { dilakukan? }\end{array}$ & $\begin{array}{l}\text { Pengarahan dilakukan di } \\
\text { awal masuk kerja sehingga } \\
\text { selanjutnya sudah dapat } \\
\text { langsung bekerja }\end{array}$ & $\begin{array}{l}\text { Mandor yang } \\
\text { memberikan } \\
\text { pengarahan sebelum } \\
\text { bekerja }\end{array}$ \\
\hline 2. & $\begin{array}{l}\text { Apakah penjelasan dan } \\
\text { pengarahan kerja sudah } \\
\text { dilakukan dengan benar dan } \\
\text { dapat dimengerti? }\end{array}$ & $\begin{array}{lr}\text { Sudah dilakukan di } & \text { awal } \\
\text { mulai kerja } & \text { dan } \\
\text { pengawasan } & \text { juga } \\
\text { dilakukan supaya dapat } \\
\text { melakukan tindakan jika } \\
\text { terjadi bahaya kerja }\end{array}$ & $\begin{array}{l}\text { Pengarahan sudah } \\
\text { dilakukan dan sudah } \\
\text { dimengerti }\end{array}$ \\
\hline 3. & $\begin{array}{l}\text { Apakah pengadaan APD } \\
\text { sudah cukup memadai? }\end{array}$ & $\begin{array}{l}\text { APD sudah disediakan, } \\
\text { seperti sepatu, rompi, dan } \\
\text { helm }\end{array}$ & $\begin{array}{ll}\text { APD } & \text { sudah } \\
\text { dipersiapkan } & \text { untuk } \\
\text { pekerjaan } & \end{array}$ \\
\hline 4. & $\begin{array}{l}\text { Berapa kali dilakukan } \\
\text { pengadaan APD dalam satu } \\
\text { tahun? }\end{array}$ & $\begin{array}{l}\text { Tergantung kebutuhan jika } \\
\text { rusak maka akan diganti } \\
\text { yang lebih bagus }\end{array}$ & $\begin{array}{l}\text { Kadang satu bulan } \\
\text { sekali namun tidak } \\
\text { menentu, jadi diganti } \\
\text { jika terdapat AOD } \\
\text { yang rusak }\end{array}$ \\
\hline 5. & $\begin{array}{l}\text { Apakah anda mengetahui } \\
\text { fungsi dan cara pemakaian } \\
\text { APD yang ada pada } \\
\text { pekerjaan anda }\end{array}$ & $\begin{array}{l}\text { APD yang digunakan sudah } \\
\text { familiar jadi sudah tau }\end{array}$ & $\begin{array}{l}\text { Sudah diberikan } \\
\text { arahan }\end{array}$ \\
\hline
\end{tabular}




\begin{tabular}{|c|c|c|c|}
\hline \multirow[t]{2}{*}{ No } & \multirow[t]{2}{*}{ Pertanyaan } & \multicolumn{2}{|c|}{ Hasil Wawancara } \\
\hline & & Bapak R (Pengawas) & \multirow{2}{*}{$\begin{array}{l}\text { Bapak L (Karyawan) } \\
\text { Mungkin di beberapa } \\
\text { tempat }\end{array}$} \\
\hline 6. & $\begin{array}{l}\text { Apakah di tempat kerja ini } \\
\text { terindikasi kebisingan? }\end{array}$ & $\begin{array}{lr}\text { Beberapa tempat } & \text { yang } \\
\text { menggunakan } & \text { mesin } \\
\text { menghasilkan suara bising }\end{array}$ & \\
\hline 7. & $\begin{array}{l}\text { Jika ditemukan tindakan } \\
\text { pekerja atau kondisi yang } \\
\text { tidak aman, bagaimana } \\
\text { prosedur penyelesaian yang } \\
\text { dilakukan? }\end{array}$ & $\begin{array}{lr}\text { Pengawas } & \text { melakukan } \\
\text { pengawasan } & \text { sehingga } \\
\text { diarahkan } & \text { untuk } \\
\text { melakukan } & \text { pekerjaan } \\
\text { dengan benar } & \end{array}$ & $\begin{array}{l}\text { Pengawas melakukan } \\
\text { pengawasan dan } \\
\text { nanti dilakukan } \\
\text { pengendalian yang } \\
\text { sesuai }\end{array}$ \\
\hline 8. & $\begin{array}{l}\text { Apakah peralatan atau mesin } \\
\text { yang digunakan untuk } \\
\text { bekerja sudah memadai dan } \\
\text { aman? }\end{array}$ & $\begin{array}{l}\text { Semua alat yang digunakan } \\
\text { sudah aman }\end{array}$ & $\begin{array}{l}\text { Mesin yang ada sudah } \\
\text { aman }\end{array}$ \\
\hline 9. & $\begin{array}{l}\text { Apakah SOP atau standar } \\
\text { pengoperasian setiap mesin } \\
\text { sudah ada? }\end{array}$ & $\begin{array}{l}\text { Sudah ada arsip dan hanya } \\
\text { yang memiliki wewenang } \\
\text { dapat mengoperasikan } \\
\text { mesin kerja }\end{array}$ & $\begin{array}{lr}\text { Setiap mesin } \\
\text { dioperasikan } & \text { oleh } \\
\text { orang yang } & \text { sudah } \\
\text { ditentukan } & \end{array}$ \\
\hline 10. & $\begin{array}{l}\text { Apakah ada perawatan } \\
\text { khusus terhadap peralatan } \\
\text { atau mesin? Jika ada, apakah } \\
\text { saya dapat melihat } \\
\text { dokumentasi terkait jadwal } \\
\text { perawatan dan } \\
\text { kebersihannya? }\end{array}$ & $\begin{array}{l}\text { Perawatan dilakukan jika } \\
\text { terdapat mesin rusak dan } \\
\text { sesuai alur yang sudah } \\
\text { ditentukan }\end{array}$ & $\begin{array}{l}\text { Mesin diperbaiki jika } \\
\text { rusak oleh mekanik } \\
\text { yang bertugas }\end{array}$ \\
\hline 11. & $\begin{array}{l}\text { Menurut anda safety poster } \\
\text { dan rambu-rambu K3 yang } \\
\text { ada sudah cukup? }\end{array}$ & Masih belum banyak & Masih sedikit \\
\hline \multicolumn{4}{|c|}{ Konsekuensi } \\
\hline 1. & $\begin{array}{l}\text { Sebutkan keluhan atau } \\
\text { dampak dari pekerjaan yang } \\
\text { anda lakukan terhadap } \\
\text { kesehatan anda? }\end{array}$ & $\begin{array}{l}\text { Di bagian pengelasan } \\
\text { sering merasa silau dan } \\
\text { juga akibat dari proses } \\
\text { pengelasan }\end{array}$ & $\begin{array}{ll}\text { Kalo saat corona ini } \\
\text { kesehatan } & \text { lebih } \\
\text { diperhatikan } & \end{array}$ \\
\hline 2. & 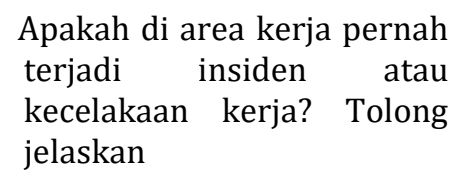 & $\begin{array}{l}\text { Pernah, tapi hanya ringan } \\
\text { saja seperti terjepit }\end{array}$ & $\begin{array}{l}\text { Insiden kecil pernah } \\
\text { terjadi karena proses } \\
\text { kerja }\end{array}$ \\
\hline 3. & $\begin{array}{l}\text { Jika terjadi kecelakaan kerja } \\
\text { atau keadaan darurat, } \\
\text { tindakan apa yang } \\
\text { dilakukan? Tolong jelaskan }\end{array}$ & $\begin{array}{l}\text { Langsung dibawa ke IGD } \\
\text { terdekat }\end{array}$ & $\begin{array}{l}\text { Dibawa langsung ke } \\
\text { klinik terdekat kalo di } \\
\text { perusahaan juga ada } \\
\text { untuk alat } \\
\text { pertolongan pertama } \\
\text { untuk kejadian yang } \\
\text { bisa ditangani }\end{array}$ \\
\hline 4. & $\begin{array}{l}\text { Apa setiap kecelakaan kerja } \\
\text { yang terjadi dilakukan } \\
\text { pencatatan dengan baik? Jika } \\
\text { ada datanya, bolehkah saya } \\
\text { mendapatkan datanya }\end{array}$ & $\begin{array}{l}\text { Langsung dibawa ke IGD } \\
\text { kalo parah, tapi kalo ringan } \\
\text { bisa ditangani di tempat } \\
\text { dan belum dilakukan } \\
\text { pencatatan untuk kasus } \\
\text { terjadi }\end{array}$ & $\begin{array}{lr}\text { Hanya ranges } & \text { proses } \\
\text { penanganan } & \text { yang } \\
\text { dilakukan oleh pihak } \\
\text { kerja }\end{array}$ \\
\hline
\end{tabular}




\subsection{Pembahasan}

\subsubsection{Hasil Observasi Lingkungan Kerja}

Dari hasil observasional yang telah dilakukan di lima area kerja yaitu bagian pembesian, mixer, pencetakan, pemuatan, dan laboratorium pengecekan beton yang dipaparkan pada tabel 1 diatas dapat disimpulkan bahwa masih terdapat beberapa sub indikator yang belum terpenuhi di setiap area kerja. Area kerja pembesian didapatkan hasil dari 17 sub indikator terdapat 11 sub indikator yang masih belum terpenuhi, area kerja mixer didapatkan hasil dari 17 sub indikator terdapat 10 sub indikator yang masih belum terpenuhi, area kerja pencetakan didapatkan hasil dari 17 sub indikator terdapat 10 sub indikator yang masih belum terpenuhi, area kerja pemuatan didapatkan hasil dari 17 sub indikator terdapat 4 sub indikator yang masih belum terpenuhi, dan area kerja laboratorium pengecekan beton didapatkan hasil dari 17 sub indikator terdapat 8 sub indikator yang masih belum terpenuhi.

Pada Indikator Fasilitas Tempat Kerja yang belum memenuhi standar yaitu belum tersedia alat P3K di lima area kerja yang mana hal dapat meningkatkan risiko kecelakaan kerja karena alat P3K merupakan peralatan yang penting untuk melakukan pertolongan pertama apabila terjadi kecelakaan kerja (Alfiansah et al., 2020). Juga belum tersedia poster penanda area kerja berbahaya di lima area kerja, dan belum tersedia poster penanda penggunaan APD sesuai area kerja di lima area kerja. Selain itu, Alat Pemadam Api Ringan (APAR) di lima area kerja belum tersedia dan belum tersedia tempat sampah untuk barang yang sudah dipakai di empat area kerja yaitu area kerja pembesian, mixer, pencetakan, dan laboratorium pengecekan beton. Pengawasan akan mempengaruhi Kesehatan dan Keselamatan Kerja setiap pekerja. Hal ini sesuai dengan penelitian yang dilakukan oleh Wiraandika (2018) tentang pengaruh pengawasan terhadap keselamatan dan kesehatan kerja dengan hasil bahwa thitung 2,346>t tabel 1,99 yang artinya pengawasan memiliki pengaruh terhadap kesehatan dan keselamatan kerja. pengawasan yang baik akan meningkatkan kesehatan dan keselamatan kerja yang ada.

Pada indikator Tempat Penyimpanan Alat yang belum memenuhi standar yaitu material atau alat belum tersimpan dengan rapi berdasarkan jenisnya di area kerja pembesian, mixer, pencetakan, dan laboratorium pengecekan beton. Selain itu, Alat-alat belum diletakkan berdasarkan jenisnya di area kerja pembesian, mixer, pencetakan, dan laboratorium pengecekan beton serta material yang sudah tidak digunakan belum dipisahkan dengan material yang masih dapat digunakan di area kerja pembesian.

Pada indikator Pengaman Mesin sudah sesuai dengan standar dan hanya perlu dilakukan pengawasan dan peningkatan pengamanan setiap mesin kerja yang digunakan. Pada indikator Desain Tempat Kerja yang belum memenuhi standar yaitu belum terdapat pembatas setiap jenis pekerjaan di area kerja pembesian, mixer, dan pencetakan. Juga barang-barang atau alat-alat kerja yang tersedia belum tersusun rapi di area kerja pembesian, mixer, pencetakan dan laboratorium pengecekan beton. Selain itu, juga yang belum sesuai yaitu permukaan lantai area tempat kerja belum rata atau ada yang licin di area kerja pembesian, mixer dan pencetakan. 


\subsubsection{Hasil Pengukuran Lingkungan Kerja}

Hasil pengukuran intensitas pencahayaan di area kerja pembesian, pencetakan dan pemuatan sudah sesuai standar yang ditetapkan dengan hasil pengukuran 827 lux, 578 lux, dan 655 lux. Sedangkan hasil pengukuran intensitas pencahayaan di area kerja mixer dan laboratorium belum sesuai standar yang ditetapkan dengan hasil pengukuran 204 lux dan 147 lux. Sebagaimana persyaratan kesehatan lingkungan kerja industri sesuai dengan Keputusan Menteri Kesehatan Republik Indonesia Nomor 1405/MENKES/SK/XI/2002 Tentang Persyaratan Kesehatan Lingkungan Kerja Perkantoran dan Industri untuk jenis pekerjaan yang dilakukan secara rutin maka pencahayaannya adalah 300 Lux. Lingkungan kerja yang baik akan mendukung kinerja pekerja sehingga dapat bekerja dengan aman dan nyaman (Parashakti \& Putriawati, 2020). Pada suatu pekerjaan cahaya sangat dibutuhkan untuk melihat suatu objek. Pantulan cahaya dari objek akan mempengaruhi kejelasan penglihatan, sehingga jika cahaya kurang atau berlebih akan mempengaruhi kenyamanan penglihatan (Widiyantoro et al., 2017). Penerangan yang sangat besar juga akan menimbulkan rasa panas juga gelisah saat bekerja dan sebaliknya, jika penerangan kurang maka akan membuat ngantuk dan mengganggu konsentrasi saat bekerja sehingga dapat menimbulkan kesalahan saat bekerja (Suri \& Martian, 2017). Selain itu, Tinggi rendah pencahayaan yang ada akan menimbulkan keluhan psikis seseorang, baik mengalami kelelahan karena pencahayaan yang kurang maupun perasaan tidak nyaman karena pencahayaan yang berlebihan (Feronika et al., 2014). Sehingga harus dilakukan Keselamatan dan Kesehatan Kerja (K3) untuk melakukan perlindungan terhadap pekerja untuk setiap potensi yang dapat menyebabkan bahaya (Putera \& Harini, 2017).

Hasil pengukuran suhu di area kerja laboratorium pengecekan beton sudah sesuai standar yang karena tidak melebihi nilai ambang batas yang telah ditetapkan dengan hasil pengukuran $27,1^{\circ} \mathrm{C}$. Sedangkan hasil pengukuran suhu di area kerja pembesian, mixer, pencetakan dan pemuatan belum sesuai standar karena melebihi nilai ambang batas yang telah ditetapkan dengan hasil pengukuran yaitu $29,1^{\circ} \mathrm{C}, 30,6^{\circ} \mathrm{C}, 28,2^{\circ} \mathrm{C}$, dan $29,6^{\circ} \mathrm{C}$. Sebagaimana persyaratan kesehatan lingkungan kerja sesuai dengan Peraturan Menteri Kesehatan Republik Indonesia Nomor 70 Tahun 2016 Tentang Standar dan Persyaratan Kesehatan Lingkungan Kerja Industri adalah $18-28^{\circ} \mathrm{C}$ untuk paparan selama 8 jam kerja. Lingkungan kerja yang baik akan akan mempengaruhi semangat kerja setiap pekerja, dan sebaliknya jika lingkungan kerja tidak sesuai dengan yang seharusnya maka akan semangat kerja setiap pekerja akan menurun serta menurunkan produktivitas pekerja (Elizar \& Tanjung, 2018). Potensi bahaya suhu lingkungan kerja yang panas disebabkan oleh panas matahari yang langsung kena ke area kerja dikarenakan area kerja berada di area terbuka. Suhu lingkungan kerja yang tinggi mempengaruhi peningkatan suhu tubuh sehingga dapat menyebabkan penurunan kontraksi otot yang akan menyebabkan tubuh mengalami kelelahan (Ihsan \& Salami, 2015). Kelelahan yang terjadi karena ketahanan tubuh berkurang sehingga meningkatkan kesalahan dalam melakukan pekerjaan sehingga meningkatkan risiko kecelakaan kerja (Kurniawan \& Kurniawan, 2018). Sehingga perlu dilakukan Kesehatan dan Keselamatan Kerja (K3) untuk menekan risiko kecelakaan kerja yang terjadi (Aswar et al., 2016).

Hasil pengukuran kebisingan di area kerja pembesian, pencetakan, pemuatan dan laboratorium pengecekan beton sudah sesuai dengan standar karena tidak melebihi nilai ambang batas yang telah ditetapkan dengan hasil pengukuran 74,19 dB, 80,57 dB, 73,53 dB, dan 60,29 dB. Sedangkan hasil pengukuran kebisingan di area kerja mixer belum sesuai 
standar karena melebihi nilai ambang batas yang telah ditetapkan dengan hasil pengukuran 86,15 dB. Sebagaimana persyaratan kesehatan lingkungan kerja sesuai dengan Peraturan Menteri Kesehatan Republik Indonesia Nomor 70 Tahun 2016 Tentang Standar dan Persyaratan Kesehatan Lingkungan Kerja Industri adalah 85dB untuk paparan selama 8 jam kerja. Lingkungan kerja yang baik akan mempengaruhi setiap proses kerja dari setiap tugas yang sudah diberikan atau dibebankan kepada setiap individu atau pekerja yang ada (Sitinjak, 2018). Kebisingan adalah salah satu bagian dari lingkungan kerja yang sangat kesehatan dan pekerjaan. Kebisingan yang terjadi lebih dari $70 \%$ berasal dari aktivitas industri/pabrik (Ismaila \& Odusote, 2014). Kebisingan merupakan salah satu polusi yang sangat membahayakan kesehatan telinga atau pendengaran Bunyi yang tidak dikehendaki telinga dalam jangka panjang akan merusak pendengaran, mengganggu pekerjaan, menyebabkan kesalahan komunikasi, dan kebisingan yang sangat serius dapat menyebabkan kematian (Budianto \& Katini, 2015). Dampak dari paparan kebisingan dapat menyebabkan kehilangan daya pendengaran sementara yaitu kemampuan untuk mendengar suara melemah dan kehilangan pendengaran tetap yaitu kemampuan pendengaran berkurang secara tetap dan tidak akan bisa pulih kembali (Handayani \& Hati, 2018). Selain itu, kebisingan juga dapat mengganggu kesehatan lain selain pendengaran, yaitu peningkatan tekanan darah, gangguan psikologis, gangguan fisiologi pada tubuh, serta dapat menyebabkan gangguan pada tingkah laku individu (Mukhlish et al., 2018). Hal ini sesuai dengan penelitian yang dilakukan oleh Ridwan et al (2017) yang menjelaskan bahwa terdapat hubungan antara kebisingan dengan stress kerja sehingga dapat menurunkan produktivitas dan juga menyebabkan kecelakaan kerja. Kebisingan mempengaruhi kesehatan khususnya bagian pendengaran dan juga dapat mengganggu konsentrasi pekerja dalam bekerja, sehingga kebisingan di area kerja harus dikurangi sebisa mungkin (Wijaya \& Susanty, 2017). Hal ini sesuai dengan pendapat Irvianti \& Verina (2015) yang menjelaskan bahwa suara bising di tempat kerja harus dihindarkan supaya setiap pekerja dapat melakukan pekerjaan dengan efisien. Jika terdapat kebisingan maka dapat dilakukan pemberian APT berupa ear plug supaya mengurangi intensitas bunyi yang masuk ke dalam telinga (Laziardy, 2017).

\subsubsection{Hasil wawancara}

Hasil wawancara yang telah dilakukan dapat ditarik beberapa kesimpulan yaitu Secara umum terdapat bahaya kerja di lingkungan kerja PT yang dapat menyebabkan kecelakaan kerja yang tergolong ringan dan penyelidikan terkait bahaya kerja belum dilakukan secara langsung yang mana hanya penerapan peraturan yang sudah ditetapkan. Selain itu, pengendalian bahaya kerja yang ditemukan sudah dilakukan pengendalian beberapa bahaya seperti pembuatan pengaman pintu. Pengendalian bahaya yang dilakukan merupakan bagian dari Keselamatan dan Kesehatan Kerja (K3) yang diberikan merupakan salah satu hal yang diberikan oleh perusahaan kepada karyawan supaya merasa aman saat melakukan pekerjaan sehingga pekerjaan dapat berjalan dengan lancar (Firmansyah \& Puspitasari, 2020).

Sistem kerja yang ada di PT sudah disampaikan saat pertama kali mulai bekerja yang mana pengarahan yang diberikan dapat dimengerti setiap pekerja. Namun, pengarahan seharusnya dilakukan setiap kali melakukan pekerjaan dan harus dengan benar. Safety talk akan meningkatkan K3 di tempat kerja karena dilakukan bersama dengan manajer dan pekerja (Suyono \& Nawawinetu, 2013). Hal ini sesuai dengan penelitian yang dilakukan Listyandini \& Suwandi (2019) Faktor Yang Berhubungan Dengan Tindakan Tidak Aman Pada Pekerja Di Pabrik Pupuk Npk dengan hasil p-value $(0,000)<\alpha(0,05)$ yang berarti ada hubungan 
bermakna antara tindakan tidak aman dengan safety talk. Sehingga, perlu dilakukan pengarahan secara rutin supaya meminimalisir tindakan tidak aman yang dapat menyebabkan kecelakaan kerja. Safety talk dapat dilakukan sekali seminggu dan safety briefing dilakukan sebelum melakukan pekerjaan (Rifqi \& Dyah, 2018). Untuk alat pelindung diri sudah disiapkan dari PT juga pengadaan alat pelindung diri disesuaikan dengan kebutuhan. Namun harus tetap dilakukan pengawasan supaya dapat melakukan teguran apabila pekerja tidak menggunakan APD yang sesuai (Sangaji et al., 2018). Karena penggunaan alat pelindung diri merupakan salah satu pengendalian bahaya yang dilakukan (Aryantiningsih \& Husmaryuli, 2016). Perbaikan setiap mesin yang ada dilakukan jika sudah dibutuhkan perbaikan dan setiap mesin sudah terjamin aman. Pengoperasian setiap mesin yang ada hanya dilakukan oleh orang yang ahli dibidangnya. Untuk poster K3 masih belum memadai atau masih dalam jumlah yang sedikit.

Kejadian kecelakaan kerja yang terjadi tergolong kecil seperti proses pengelasan yang mengganggu mata dan terjepit mesin kerja. Setiap kejadian kecelakaan kerja yang terjadi dilakukan penanganan yang sesuai dan membawa ke IGD terdekat serta setiap kejadian kecelakaan kerja belum dilakukan pencatatan.

\section{Simpulan}

Kesimpulan yang dapat diambil dari penelitian diatas adalah: Hasil akhir dari penelitian didapatkan hasil observasi yang belum terpenuhi dengan jumlah berbeda yaitu Area kerja pembesian terdapat 11 sub indikator, area kerja mixer 10 sub indikator, area kerja pencetakan 10 sub indikator, area kerja pemuatan 4 sub indikator, dan area laboratorium pengecekan beton 8 sub indikator. Hasil pengukuran intensitas pencahayaan di area kerja pembesian, pencetakan dan pemuatan sudah sesuai standar sedangkan area kerja mixer dan laboratorium belum sesuai standar. Suhu di area laboratorium pengecekan beton sudah sesuai standar sedangkan suhu di pembesian, mixer, pencetakan dan pemuatan belum sesuai standar. Kebisingan di area kerja pembesian, pencetakan, pemuatan dan laboratorium pengecekan beton sudah sesuai dengan standar sedangkan area kerja mixer belum sesuai standar. Berdasarkan hasil wawancara terdapat beberapa hal yang belum sesuai dengan peraturan yang berlaku.

\section{Daftar Rujukan}

Alfiansah, Y., Kurniawan, B., \& Ekawati. (2020). Analisis Upaya Manajemen K3 Dalam Pencegahan Dan Pengendalian Kecelakaan Kerja Pada Proyek Konstruksi PT. X Semarang. Jurnal Kesehatan Masyarakat, $8(5), 595-600$.

Amir, J., Wahyuni, I., \& Ekawati. (2019). Hubungan Kebisingan, Kelelahan Kerja Dan Beban Kerja Mental Terhadap Stres Kerja Pada Pekerja Bagian Body Rangka Pt. X. Jurnal Kesehatan Masyarakat (e-Journal), $7(1), 345-350$.

Aryantiningsih, D. S., \& Husmaryuli, D. (2016). Kejadian Kecelakaan Kerja Pekerja Aspal Mixing Plant (AMP) \& Batching Plant di PT. LWP Pekanbaru Tahun 2015. Jurnal Kesehatan Masyarakat Andalas, 10(2), 145150. https://doi.org/10.1134/S1028334X07080132

Aswar, E., Asfian, P., \& Fachlevy, A. F. (2016). Faktor-Faktor Yang Berhubungan Dengan Kecelakaan Kerja Pada Pekerja Bengkel Mobil Kota Kendari Tahun 2016. Jurnal Ilmiah Mahasiswa Kesehatan Masyarakat Unsyiah, 1(3), 185957.

Budianto, A. A. T., \& Katini, A. (2015). PENGARUH LINGKUNGAN KERJA TERHADAP KINERJA PEGAWAI PADA PT PERUSAHAAN GAS NEGARA (PERSERO) Tbk SBU DISTRIBUSI WILAYAH I Jakarta. Ilmiah Prodi Manajemen Universitas Pamulang, 3(1), 100-124. https://doi.org/10.37751/parameter.v4i2.42

Elizar, \& Tanjung, H. (2018). Pengaruh Pelatihan, Kompetensi, Lingkungan Kerja terhadap Kinerja Pegawai. Jurnal Ilmiah Magister Manajemen, 1(1), 46-58. https://doi.org/10.30596/maneggio.v1i1.2239 
Feronika, Rambi, E. V, \& Layuk, S. (2014). Intensitas Pencahayaan Pada Ruang Kerja PT. Manado Media Grafika. Jurnal Kesehatan Lingkungan, 3(2), 398-405.

Firmansyah, Y. R., \& Puspitasari, S. T. (2020). Pengaruh Pemberian Sarung Tangan Kerja Terhadap Produktivitas pada Pekerja ( Studi Kasus di Restoran ). Sport Science and Health, 2(11), 558.

Handayani, W. N., \& Hati, S. W. (2018). Pengaruh Lingkungan Kerja Fisik Terhadap Produktivitas Kerja Karyawan Operator Bagian Produksipada Perusahaan Manufaktur Di Pt Abc Batam. Jurnal Aplikasi Administrasi, 21(1), 9-30.

Ihsan, T., \& Salami, I. R. S. (2015). Hubungan Antara Bahaya Fisik Lingkungan Kerja Dan Beban Kerja Dengan Tingkat Kelelahan Pada Pekerja Di Divisi Stamping Pt. X Indonesia. Jurnal Dampak, 12(1), 10. https://doi.org/10.25077/dampak.12.1.10-16.2015

Irvianti, L. S. D., \& Verina, R. E. (2015). Analisis Pengaruh Stres Kerja, Beban Kerja dan Lingkungan Kerja terhadap Turnover Intention Karyawan pada PT XL Axiata Tbk Jakarta. Binus Business Review, 6(1), 117-126. https://doi.org/10.21512/bbr.v6i1.995

Ismaila, S., \& Odusote, A. (2014). Noise Exposure as a factor in The Increase of Blood Pressure of Workers in a Sack Manufacturing Industry. Beni-Suef University Journal of Basic and Applied Science, 3(2), 116-121.

Kurniawan, Y., \& Kurniawan, B. (2018). Hubungan Pengetahuan, Kelelahan, Beban Kerja Fisik, Postur Tubuh Saat Bekerja, Dan Sikap Penggunaan Apd Dengan Kejadian Kecelakaan Kerja (Studi Pada Aktivitas Pengangkatan Manual Di Unit Pengantongan Pupuk Pelabuhan Tanjung Emas Semarang). Jurnal Kesehatan Masyarakat (e-Journal), 6(4), 393-401.

Laziardy, M. (2017). Kebisingan Terhadap Kelelahan Kerja Pada Pekerja Logam Bagian Produksi. Higeia Journal of Public Health Research and Development, 1(2), 84-94.

Listyandini, R., \& Suwandi, T. (2019). Faktor Yang Berhubungan Dengan Tindakan Tidak Aman Pada Pekerja Di Pabrik Pupuk Npk. Hearty, 7(1), 1-10. https://doi.org/10.32832/hearty.v7i1.2299

Mukhlish, W. I. N., Sudarmanto, Y., \& Hasan, M. (2018). Pengaruh Kebisingan Terhadap Tekanan Darah dan Nadi pada Pekerja Pabrik Kayu PT. Muroco Jember. Jurnal Kesehatan Lingkungan Indonesia, 17(2), 112118. https://doi.org/10.14710/jkli.17.2.112-118

Ningrum, N. L., Prasetya, A., \& Riza, M. F. (2014). Pengaruh Lingkungan Kerja Terhadap Kinerja Karyawan (Studi pada Karyawan Auto 2000 Sukun Malang). Jurnal Administrasi Bisnis (JAB), 11(1), 1-9.

Odi, K. D., Purimahua, S. L., \& Ruliati, L. P. (2018). Hubungan Sikap Kerja, Pencahayaan Dan Suhu Terhadap Kelelahan Kerja Dan Kelelahan Mata Pada Penjahit Di Kampung Solor Kupang 2017. Ikesma, 14(1), 6576. https://doi.org/10.19184/ikesma.v14i1.10408

Parashakti, R. D., \& Putriawati. (2020). Pengaruh Keselamatan Dan Kesehatan Kerja (K3), Lingkungan Kerja Dan Beban Kerja Terhadap Kinerja Karyawan. Jurnal Ilmu Manajemen Terapan, 1(3), 290-304. https://doi.org/10.31933/jimt.v1i3.113

Prayoga, G. A. N., Heynoek, F. P., \& Yudasamara, D. S. (2020). Pengembangan Model Pembelajaran Kebugaran Jasmani Dengan Modifikasi Permainan Pada Siswa Kelas VIII. Sport Science and Health, 2(10), 500-510. http://journal2.um.ac.id/index.php/jfik/index

Putera, R. I., \& Harini, S. (2017). Pengaruh Keselamatan dan Kesehatan Kerja (K3) Terhadap Jumlah Penyakit Kerja dan Jumlah Kecelekaan Kerja Karyawan pada PT. HANEI INDONESIA. Jurnal Visionida, 3(1), 4253.

Ridwan, V. A., Wahyuni, I., \& Setyaningsih, Y. (2017). Hubungan Lingkungan Fisik Kerja Dan Beban Mental Dengan Kejadian Stres Kerja Pada Pekerja Laundry Di PT. Sandang Asia Maju Abadi Semarang. Jurnal Kesehatan Masyarakat (e-Journal), 5(5), 406-412.

Rifqi, A. R., \& Dyah, N. E. (2018). Hubungan Karakteristik Pekerja Dan Lingkungan Kerja Dengan Kejadian Kecelakaan Kerja Di Pt Waskita Karya (Persero). Journal of Industrial Hygiene and Occupational Health, $3(1), 1-12$.

Sangaji, J., Jayanti, S., \& Lestantyo, D. (2018). Faktor-Faktor Yang Berhubungan Dengan Perilaku Tidak Aman Pekerja Bagian Lambung Galangan Kapal Pt X. Jurnal Kesehatan Masyarakat (e-Journal), 6(5), 563-571.

Senata, W., Nuridja, M., \& Suwena, K. R. (2014). Pengaruh Lingkungan Kerja terhadap Produktivitas Kerja Karyawan UD. Kembang Sari Kabupaten Badung Tahun 2012. Jurnal Pendidikan Ekonomi Undiksha, $4(1)$. 
Sitinjak, L. N. (2018). Pengaruh Lingkungan Kerja Terhadap Kepuasan Kerja Karyawan (Studi pada Karyawan PT. Mitra Pinasthika Mustika Rent Tangerang Selatan). Jurnal Administrasi Bisnis (JAB), 60(2), 162-168.

Suri, F., \& Martian, E. (2017). Pengaruh Pencahayaan Ruang Kerja Terhadap Stres Kerja Karyawan Biro Perencanaan dan Kerjasama Universitas Sumatera Utara. Jurnal Diversita, 3(2), 9. https://doi.org/10.31289/diversita.v3i2.1255

Suyono, K. ., \& Nawawinetu, E. D. (2013). Hubungan Antara Faktor Pembentuk Budaya Keselamatan Kerja dengan Safety Behavior di PT DOK dan Perkapalan Surabaya Unit Hull Constructio. The Indonesian Journal of Occupational Safety and Health, 2(1), 64-67.

Widiyantoro, H., Mulyadi, E., \& Vidiyanti, C. (2017). Analisis Pencahayaan Terhadap Kenyamanan Visual Pada Pengguna Kantor (Studi Kasus:Kantor PT Sandimas Intimitra Divisi Marketing di Bekasi). Jurnal Arsitektur, Bangunan \& Lingkungan, 6(2), 65-70.

Wijaya, H., \& Susanty, E. (2017). Pengaruh Lingkungan Kerja Terhadap Kinerja Pegawai Pada Instansi Pemerintah Daerah Kabupaten Musi Banyuasin (Studi Kasus Dinas Pertambangan Dan Energi Kabupaten Musi Banyuasin). Jurnal Ecoment Global, 2(1), 40-50. https://doi.org/10.35908/jeg.v2i1.213

Wiraandika, G. (2018). Pengaruh pengawasan, disiplin dan lingkungan kerja terhadap keselamatan dan kesehatan kerja karyawan pada pt. bumi mulia perkasa dumai. Jurnal Tepak Manajemen Bisnis, X(1), 51-63. 